\title{
UPAYA MENINGKATKAN MANAJEMEN KOMUNIKASI DALAM RUMAH TANGGA SERTA MEMBANGUN KETAHANAN KELUARGA DI ERA COVID 19
}

\author{
Rina Dwi Wulandari ${ }^{1}$, Rosmawati ${ }^{2}$, Rijalus Shalihin ${ }^{3}$ \\ Universitas Muhammadiyah Palembang \\ Prodi Ekonomi Syariah Fakultas Agama Islam \\ rinadwiwulandari3@gmail.com,rosma8892@gmail.com,rijalushfaiump@gmail.com
}

\begin{abstract}
Abstrak
Artikel ini ingin menjelaskan bahwa pandemik Coronavirus Disease atau COVID-19 mendistrupsi tatanan kehidupan keluarga. Sejak pemerintah menekannya physical distancing atau penjagaan jarak secara tidak langsung memberikan waktu nyaris 24 jam berada di rumah. Pandemi COVID-19 sangat menguji ketahanan keluarga. Secara positif, dampak karantina mandiri memberi waktu untuk saling mengenal secara mendalam antar anggota keluarga. Disisi lain, semakin sering anggota keluarga bertemu meningkatkan rasa jenuh yang kemudian menimbulkan gesekan terjadi. Tulisan ini menulis bagaimana upaya meningkatkan manajemen komunikasi keluarga saat Pandemi COVID-19 sehingga tercipta keluarga yang harmonis dan sejahtera, melakukan komunikasi antar pribadi, tanggung jawab pada lingkungan dan keluarga, intensitas dan arah komunikasi dengan atmosfir yang harmonis, pola asuh hidup sehat walaupun dalam suasana physical distancing atau penjagaan jarak sesuai anjuran pemerintah.
\end{abstract}

Kata Kunci: Manajemen Komunikasi Keluarga; Pandemik Covid-19; Ketahanan Keluarga.

\section{Abstract}

This article wants to explain that the Coronavirus Disease or COVID-19 pandemic is disrupting the fabric of family life. Since the government has pressed physical distancing, it has indirectly provided almost 24 hours of time at home. The COVID-19 pandemic is particularly testing the resilience of families. In a positive way, the impact of self-quarantine provides time to get to know each other deeply between family members. On the other hand, the more often family members meet increases the feeling of boredom which then causes friction to occur. This paper writes about efforts to improve family communication management during the COVID-19 pandemic so as to create a harmonious and prosperous family, conduct interpersonal communication, responsibility for the environment and family, intensity and direction of communication with a harmonious atmosphere, parenting a healthy life even in an atmosphere. physical distancing or distance maintenance as recommended by the government.

Keywords : Family Communication Management; Covid-19 Pandemic; Family Resilience.

\section{PENDAHULUAN}

Pandemik Coronavirus Disease atau COVID-19 telah mendistupsi kehidupan tatanan sosial umat manusia. Arif Satria (2020) mengistilahkan, wabah COVID-19 menginstall ulang tata seluruh kehidupan manusia. Hanya dalam kurang tiga bulan, virus ini sudah menyebar hampir di seluruh negara di dunia dan menginfeksi 7.055 .6196 orang, 403.755 meninggal dan 3.446.882 dinyatakan sembuh. Sedangkan di Indonesia berdasarkan data worldmeters.info pertanggal 07 Juni 2020, jumlah orang yang terinfeksi mencapai 31.186 orang dengan jumlah meninggal dan sembuh berturut-turut sebanyak 1.851 dan 10.498 .

Distrupsi COVID-19 menyebabkan krisis multi-dimensi. Bermula dari tragedi kemanusian yang menyebabkan kecemasan manusia terhadap kesehatan, meluas kepada sektor 
ekonomi, industri, pendidikan, keagamaan, pemerintahan, serta pangan dan badai berita palsu atau krisis infodemic. Lebih dari 70 negara kemudian melakukan lockdown menyebabkan terpukulnya berbagai sektor ekonomi. Beberapa sektor yang terpukul keras misalnya seperti sektor jasa, terutama industri yang melibatkan interaksi fisik seperti perdagangan ritel, rekreasi dan perhotelan dan transportasi.

Implikasi ekonomi juga tidak bisa dianggap remeh. Salah satu dampak ekonomi yang begitu nyata adalah daya beli masyarakat menurun, pekerja dirumahkan, bahkan sampai diputus hubungan kerja (PHK), kemiskinan meningkat, mobilitas orang dan barang terganggu dan terdepresiasinya nilai tukar rupiah terhadap dollar Amerika sampai menyentuh Rp. 16.400-an per USD8.

Sesuai anjuran Badan Kesehatan dunia (WHO), Pemerintah membuat kebijakan Pembatasan sosial bersekala (PSBB) mengurangi penyebaran virus corona di beberapa provinsi yang tercap rawan atau dalam zona merah. Selain itu, antara lain melewati swakarantina atau diam di rumah atau stay at home untuk mengurangi perkumpulan yang menjadi penyebab cepatnya penyebaran virus ini antar manusia. Membatasi bertemu dengan orang, termasuk bekerja dari rumah istilah populernya work from home (WFH). Seringnya berada di rumah berhari-hari sejak pemerintah menekankan physical distancing atau penjagaan jarak memberikan dampak nyata pada kehidupan keluarga. Sebagai unit terkecil dalam masyarakat, dampak pandemi COVID-19 bisa dilihat dari dua sisi, baik negatif maupun positif. Secara positif, misalnya, masa karantina mandiri secara tidak langsung memberikan waktu untuk lebih saling mengenal secara mendalam antar-anggota keluarga. Disisi lain, nyarisnya selama 24 jam berada di rumah rentan menimbulkan berbagai gesekan. Semakin sering anggota keluarga bertemu, semakin sering gesekan terjadi.

Wabah COVID-19 juga sangat menguji ketahanan keluarga. Pandemik COVID-19 mengajarkan kita memahami bagaimana seharusnya manajemen komunikasi keluarga. Tiap entitas keluarga harus mengerti peran dan tanggung jawabnya. Seorang bapak harus tahu perannya sebagai ayah dan pemimpin keluarga yang baik. Begitu juga ibu, harus tahu perannya sebagai sosok istri sekaligus ibu biologis bagi anak-anaknya. Begitu juga seorang anak, harus tahu bagimana peran nya sebagai anak dari kedua orangtuanya. Artikel ini akan menulis bagaimana manajemen komunikasi organisasi keluarga pada pandemik COVID-19.

\section{METODE PENELITIAN}

Untuk menguraikan masalah ini dibutuhkan sumber penelitian berupa bahan primer dan bahan sekunder berupa buku-buku, teks, dan artikel-artikel jurnal. Metode penelitian ini bersifat yuridis normative empiris dan jenis penelitian kualitatif.

\section{HASIL DAN PEMBAHASAN}

\section{Konsep Komunikasi Keluarga}

Konsep keluarga menurut sejumlah ahli adalah sebagai unit sosial-ekonomi terkecil dalam masyarakat yang merupakan landasan dasar dari semua institusi, merupakan kelompok primer yang terdiri dari dua atau lebih orang yang mempunyai jaringan interaksi interpersonal, hubungan darah, hubungan perkawinan, dan adopsi. Berdasarkan Undangundang No 52 Tahun 2009 tentang Perkembangan Kependudukan dan Pembangunan Keluarga Pasal 1 Ayat (6) pengertian keluarga adalah unit terkecil dalam masyarakat yang terdiri dari suami isteri, atau suami, istri dan anaknya, atau ayah dan anaknya, atau ibu dan anaknya. Konsep Keluarga dalam Kitab Suci al Qur'an:

a. Firman Allah dalam Surat At-Tahrim Ayat 6:

"Hai orang-orang yang beriman, peliharalah dirimu dan keluargamu dari api neraka yang bahan bakarnya adalah manusia dan batu; penjaganya malaikat-malaikat yang kasar, yang keras, yang tidak mendurhakai Allah terhadap apa yang diperintahkan-Nya kepada mereka dan selalu mengerjakan apa yang diperintahkan". 
b. Firman Allah dalam Surat Al-Furqon Ayat 74 :

"Dan orang-orang yang berkata: "Ya Tuhan kami, anugerahkanlah kepada kami istriistri kami dan keturunan kami sebagai penyenang hati (kami), dan jadikanlah kami imam bagi orangorang yang bertakwa".

Keluarga juga seperti diamahkan oleh Undang-Undang Nomor 52 Tahun 2009 Tentang Perkembangan Kependudukan dan Pembangunan Keluarga: Bab II: Bagian Ketiga Pasal 4 Ayat 2, bahwa pembangunan keluarga bertujuan untuk meningkatkan kualitas keluarga agar dapat timbul rasa aman, tenteram, dan harapan masa depan yang lebih baik dalam mewujudkan kesejahteraan lahir dan kebahagiaan batin.

\section{Manajemen Tanggungjawab dalam Keluarga}

Langkah penting yang perlu dilakukan dalam menghadapi pandemi COVID-19 salah satunya dengan membentuk suatu atmosfir keluarga yang harmonis, untuk mewujudkannya memerlukan manajemen lingkungan keluarga, yaitu dengan melakukan sistem komunikasi yang dapat membentuk suatu pola hubungan yang harmonis. Pola komunikasi dimana masingmasing partisipan dapat beralih peran, diwaktu tertentu komunikator dapat berperan sebagai komunikan dan begitu sebaliknya, serta masing-masing partisipan memiliki hak suara yang sama, dan tidak boleh digantikan oleh orang lain. Sesuai dengan pemahaman bahwa keluarga sejahtera adalah keluarga yang dibentuk berdasarkan atas perkawinan yang sah, mampu memenuhi kebutuhan hidup spiritual dan materiil yang layak, bertaqwa kepada Tuhan Yang Maha Esa, memiliki hubungan yang serasi, selaras dan seimbang antar anggota dan antar keluarga dengan masyarakat dan lingkungan (Undang-Undang Republik Indonesia Nomor 52 tahun 2009).

Manajemen keluarga setidaknya mengarah pada hal-hal sebagai berikut :

a. Perencanaan, untuk membina suatu keluarga perlu dilakukan perencanaan dan kesiapan yang matang, pada masa dalam perkawinan juga tetap memiliki perencanaan manajemen yang tepat, mau dibawa kemana arah perkawinannya, idealnya adalah menjadi keluarga yang sakinah mawadah warahmah.

b. Pengorganisasian, antara suami dan isteri terjadi pengaturan kerja dan tanggungjawabnya terhadap keberlangsungan rumah tangganya secara adil dan berimbang.

c. Pengarahan, mengomunikasikan segala sesuatu secara bersama antara suami dan isteri. Dinamika dalam rumah tangga sudah sewajarnya suami/ayah/lakilaki menjadi kepala keluarga dan memimpin bahtera rumahtangganya dengan baik, mengarah pada tujuan keluarga yang harmonis, sakinah, mawadah, warahmah.

d. Pengawasan, penting memiliki kemampuan untuk mengetahui letak kesalahan sehingga tindakan koreksi dapat dilakukan sedini mungkin.

e. Koordinasi, senantiasa mengomunikasikan dalam menjalankan tugas dan tanggungjawab antar suami dan isteri saling berkoordinasi, agar tujuan bersama yang akan dicapai dapat terwujud sesuai dengan harapan.

Penjelasan selanjutnya dalam pola sistem berpikir keluarga (Iman, 2008) menguraikan pada management system thinking lebih menekankan pada kesadaran bahwa segala sesuatu berhubungan dalam satu rangkaian sistem. Berpikir sistem manajemen keluarga mengkombinasikan antara analytical thinking (kemampuan mengurai elemen-elemen suatu masalah) dengan synthetical thinking (memadukan elemen-elemen tersebut menjadi kesatuan).

\section{Manajemen Organisasi Keluarga yang Terhindar dari Pandemi COVID19}

Merujuk pada pendapat Rogers (1983) tentang sistem komunikasi adalah suatu sistem yang terdiri atas individu-individu yang saling berhubungan, yang dilambangkan oleh arus komunikasi yang terpola. Salah satu cara untuk memahami perilaku manusia adalah dengan mengamati atau memahami hubungan-hubungan sosialnya yang tercipta karena adanya proses komunikasi interpersonal. 
Jadi hubungan dalam keluarga lebih menenkankan pada kesadaran, bahwa hubungan manajemen komunikasi keluarga sangat penting dalam mengurai atau meminimalisir, serta memecahkan permasalahan yang dihadapi. Seriring dengan kondisi pandemi COVID-19 penting memberikan kesadaran kepada seluruh anggota keluarga akan bahaya COVID-19, sehingga perlu menyatukan visi dan misi dalam mencegah terpaparnya COVID-19 dalam keluarga, tentunya dengan mengacu pada standar pencegahan agar tidak terpapar COVID-19.

Pengelolaan manajemen dan komunikasi dalam keluarga, tentu tidak terlepas dari komunikasi antarpribadi, yaitu komunikasi antara seluruh anggota keluarga yang dilakukan secara lebih mendalam, agar saling memahami antara anggota keluarga, Orangtua yakni ayah dan ibu serta anak-anaknya menjalin hubungan komunikasi antarpribadi sehingga terbina hubungan yang saling pengertian diantara seluruh anggota keluarga.

Selain itu dalam manajemen keluarga tidak terlepas dari tanggungjawab, dimana tanggungjawab yang sangat mendasar adalah peranan orang tua yaitu ayah sebagai kepala keluarga, memenuhi semua kebutuhan keluarga; dan ibu sebagai ibu rumah tangga yang merawat dan mengurus rumah, mendidik serta membesarkan anak-anaknya. Atau jika terjadi peralihan atau pertukaran peran antara ibu sebagai pencari nafkah dan BRT tetap harus memerankan tanggungjawabnya secara baik.

Kebiasaan-kebiasaan yang dilakukan dan sering berulang dapat membentuk suatu budaya. Jika input tak terkendali terkait mewabahnya COVID-19 memasuki area lingkungan tempat tinggal, maka hal tersebut hanya akan dicegah penyebarannya dengan beberapa rangkaian usaha seperti pola hidup sehat, makan makanan bergizi yang seimbang, berolah raga secara teratur, jaga jarak fisik, diam dirumah, dan bekerja dari rumah sesuai himbauan dan arahan dari pemerintah. Tetapi yang sangat berperan besar dan mendasar adalah budaya hidup sehat, hal inilah yang dapat menyeimbangkan input tak terkendali. Khususnya peran ibu rumah tangga atau sebaliknya peran BRT sangat berpengaruh terhadap keberlangsungan hidup sehat dalam keluarga. Orang tua adalah suritauladan, sehingga anak dapat mencontoh perilaku positif kedua orang tuanya.

Berdasarkan kondisi dimana terdapat input terkendali, yaitu apa yang dikendalikan dan diharapkan dapat terwujud, seperti antara suami dan isteri terjalin komunikasi yang baik, keduanya dapat memenuhi tanggungjawabnya baik secara materi maupun immateri, yaitu diwujudkan adanya kelengkapan akan sarana dan prasarana seluruh kebutuhan keluarga dapat terpenuhi dengan baik. Apabila isteri turut bekerja, tetapi suami tetap merupakan penopang tanggungjawab nomor satu dalam memenuhi tanggungjawab kebutuhan keluarga. Oleh karena pada setiap tanggungjawab memiliki konsekuensi. Hal demikian yang saat ini dialami beberapa rumah tangga di masa pandemi COVID-19.

Kondisi normal sebelum pandemi COVID-19, umumnya tanggungjawab utama isteri adalah, merawat rumah tangganya, menjaga dan merawat harta suami, mendidik, mengasuh, dan merawat anak-anaknya, dengan demikian pembagian tanggungjawab juga seimbang. Namun dengan adanya pandemi COVID-19, terjadi kondisi dimana tidak sedikit para suami sebagai kepala keluarga mengalami pemutusan hubungan kerja, sehingga tidak sedikit pula yang mengalami peralihan peran suami menjadi BRT. Oleh karena itu, hubungan antara suami dan isteri memiliki komitmen dan kualitas inovasi dalam memperbaiki hubungan secara besar hati.

Menjaga dan melestarikan budaya keluarga, tidak melupakan tradisi dan kebiasaankebiasaan yang baik, dan memiliki unsur edukasi guna tetap menjadikan keluarga adalah tempat ternyaman untuk mendidik anak-anak. Serta aturan-aturan dalam keluarga yang selalu tetap dipatuhi, menjadikan kebiasaan yang positif dalam keluarga. Membiasakan dan menumbuhkan pada anak untuk senantiasa memiliki rasa tanggungjawab, mentaati aturan yang berlaku dimasyarakat dan keluarga, bertindak dengan didasari akhlak yang baik. 
Menjaga kualitas, kuantitas, intensitas, understanding, sehingga terwujud hubungan yang harmonis. Diantara suami dan isteri melakukan kerjasama secara sinergi dalam menjaga keutuhan rumahtangga atau keluarganya, antara orang tua dan anak juga terjalin hubungan yang harmonis. Kerjasama dan bertanggungjawab dalam keluarga, menjaga, merawat, serta mendidik anak-anaknya. Apabila pembagian tanggungjawab yang seimbang, maka dimungkinkan lebih cenderung terwujud. Sebagai suatu output yang dikehendaki, maka antara suami dan isteri melakukan komunikasi dengan usaha untuk kesejahteraan keluarga. Melakukan tanggungjawab sebagai orangtua dengan memberikan perlakuan yang harmonis, adil, beradab, dalam mendidik anak-anaknya.

Berlanjut pada tahapan Output Dikehendaki, seperti dimasa pandemi COVID19, keluarga terjaga dari terpapar wabah COVID-19, anak-anak dididik untuk senantiasa hidup dengan pola yang sehat. Menerapkan nilai-nilai agama, karena agama apapun mengajarkan pola hidup bersih, sehat, seimbang. Hidup dengan tidak berlebihan makan makanan yang cukup seimbang dan sehat, olah raga yang cukup dan teratur, istirahat yang cukup secara terukur. Sehingga apabila anak-anaknya tumbuh dengan akhlak yang mulia, orang tua juga memberikan suri tauladan yang baik, maka akan tercipta keluarga yang bahagia dan sejahtera, karena orang tua juga bertanggungjawab penuh dalam memenuhi semua kebutuhan anak-anaknya, baik materiil dan nonmateriil. Terwujudlah suatu keluarga yang SAMAWA (sakinah, mawadah, dan warahmah). Sebagai contoh output dikehendaki cerminan pola asuh hidup sehat secara mental akan menghasilkan output yang positif, yakni apabila anak hidup dalam toleransi, membentuk pribadi yang sabar; Bila anak hidup dengan diberi semangat, maka ia mempunyai harga diri; Bila anak hidup dalam pujian, maka ia dapat lebih menghargai orang lain; Bila anak hidup dengan kejujuran, maka ia belajar tentang sikap keadilan; Bila anak hidup dalam rasa aman, maka ia belajar mempercayai orang lain; Bila anak hidup dengan penuh cobaan, maka ia belajar menjadi diri yang mandiri; Bila anak hidup dalam pengakuan dan persahabatan, maka ia belajar mencintai sesama dalam hidup ini.

Karena anak-anak tumbuh dan belajar dari lingkungan keluarga dan masyarakat. Oleh karena itu penting khususnya bagi orang tua untuk senantiasa bersikap dan berperilaku yang sarat dengan memberikan contoh positif. Maka anak akan memiliki ettitude yang baik, sesuai dengan harapan dari orang tuanya. Selain itu sebagai orang tua sudah seharusnya terbiasa bersikap terbuka dalam menghadapi permasalahan yang timbul, mengajak anak untuk berdiskusi atas permasalahan yang sedang dihadapi, menggunakan sistem demokrasi dan keterbukaan dalam keluarga, sehingga semua permasalahan mendapatkan solusi dan dapat dipecahkan dengan baik, tanpa menimbulkan suatu konflik yang baru.

Orang tua bekerja khususnya Ibu bekerja sering kali merasa bersalah ketika harus meninggalkan anak di rumah. Atau sebaliknya suami merasa bersalah karena menjadi BRT, kurang merasa bertanggung jawab, merasa tidak sempurna sebagai pria, wibawanya menjadi turun dimata isteri, kerabat keluarga, dan anak. Tidak perlu khawatir, dengan cara yang tepat, tetap bisa menjadi orang tua yang membesarkan anak dengan baik meskipun bekerja atau beralih peran dalam keluarga. Tentu ada akibat yang timbul ketika seorang ibu sibuk dengan pekerjaannya, atau ayah menjadi BRT. Guna mewujudkan manajemen jaringan komunikasi keluarga agar tercipta keluarga yang harmonis dan sejahtera terhindar dari pandemi COVID19, maka diperlukan beberapa cara yang bisa ditempuh oleh ibu yang bekerja atau ayah sebagai BRT adalah :

1. Manajemen waktu dengan baik; hubungan suami, isteri dan anak memerlukan waktu yang berkualitas untuk berkumpul secara fisik. Waktu yang dibutuhkan tidak perlu lama, yang penting suami, isteri konsisten meluangkan waktu bersama anak setiap hari. Bagi ibu yang bekerja, sedapat mungkin mendapatkan pekerjaan di lingkungan yang ramah terhadap keluarga. 
2. Jadikan waktu dengan anak sebagai pertemuan yang berkualitas; antara suami, isteri dan anak memiliki quality time.

3. Jalin komunikasi yang baik dengan pihak yang mengurus anak; saat bekerja, seorang Ibu biasa menitipkan anak kepada pengasuh, entah itu baby sitter, nenek ataupun sanak keluarga lainnya.

4. Jangan ganti kasih sayang dengan uang; sebagai orang tua, janganlah menggunakan uang sebagai pengganti waktu ataupun kasih sayang.

5. Pengawasan anak itu perlu; penelitian menunjukkan bahwa anak yang bermasalah mayoritas berasal dari keluarga yang kurang mengawasi anaknya. Sangat penting bagi orang tua untuk mengetahui dimana anaknya, sedang bersama siapa dan berbuat apa.

\section{KESIMPULAN}

Implementasi manajemen komunikasi keluarga dan berpikir sistem dalam mengelola keluarga agar tetap harmonis sangat penting pada saat pandemi COVID-19. Tetap menjaga input terkendali (pendapatan terjaga, kualitas pendidikan anak tetap terlaksana sesuai target, pendidikan agama dapat lebih diperdalam, tercipta budaya hidup sehat dalam keluarga). Senantiasa menjaga komunikasi antar pribadi, saling bertanggungjawab dalam menjaga kebersihan diri dan keluarga dengan pola hidup yang sehat, serta terbuka dalam mengomunikasikan segala permasalahan yang ada dalam keluarga. Mengarahkan terwujudnya output yang dikehendaki seperti; anakanak terawat baik secara fisik maupun mental, tercipta keluarga yang SAMAWA.

Memenuhi harapan dalam mewujudkan manajemen komunikasi keluarga agar tercipta keluarga yang harmonis dan sejahtera, maka diperlukan beberapa cara yang bisa ditempuh oleh ibu yang bekerja adalah: (1) Manajemen waktu dengan baik; (2) Jadikan waktu dengan anak sebagai pertemuan yang berkualitas; (3) Jalin komunikasi yang baik dengan pihak yang mengurus anak; (4) Jangan ganti kasih sayang dengan uang; dan (5) Sangat penting dilakukan pengawasan pada anak. Sehingga sangat perlu dan penting memberikan perhatian yang cukup kepada anak, karena biasanya anak yang bermasalah mayoritas berasal dari keluarga yang kurang mengawasi anaknya. Sangat penting bagi orang tua untuk mengetahui dimana anaknya, sedang bersama siapa dan berbuat apa.

\section{A. Buku-Buku}

\section{DAFTAR PUSTAKA}

Cangara H. 2002. Pengantar Ilmu Komunikasi. Jakarta(ID): PT Raja Grafindo Persada.

Handoko, Hani T. 2001. Manajemen Personalia dan Sumber Daya Manusia. Yogyakarta(ID): BPFE.

Iman. 2008. Berpikir Kritis: Sebuah Pengantar. Jakarta(ID): Erlangga Kadarsih R. 2009. Teori Penetrasi Sosial dan Hubungan Interpersonal. Jurnal Media Komunikasi dan Dakwah, Volume 10 (1): 53-66. Januari-Juni.

Kuswanti. 2017. Pola Asuh Anak sebagai cerminan perilaku, Majlis ilmu: Krukut

Lemhannas RI. 2015. "Modul bidang studi sistem manajemen nasional". Ketahanan Nasional RI.

Rangkuti F. 2001. Measuring Customer Satisfaction, Jakarta(ID):.Penerbit PT. Gramedia Pustaka Utama,

Rogers, Everett M., 1983, Diffusion of Innovations. London(ING): The Free Press. Satria A. 2020. Install ulang tata kehidupan manusia karena mewabahnya COVID-19.

\section{B. Website}

http://seknas@ PEKKA.or. id Manajemen Komunikasi Keluarga Saat Pandemi COVID-19 Jurnal Sosial dan Budaya Syar-i. Volume 7 Nomor 8 (2020). ISSN: 2356-1459. E-ISSN: 2654-9050 - 721

http://ejournal.uin-suka.ac.id/dakwah/jurnaldakwah/article/view/414/391. 